\title{
Energy and Climate Analysis of Greenhouse System for Tomatoes Cultivation using CFD and Open Studio Energy Plus Software
}

\author{
N.Y Dahlan ${ }^{1 *}$, Ahmad Amiruddin ${ }^{1}$, Nguyen Duc Luong ${ }^{3}$, Siti Zaharah Sakimin ${ }^{2}$ \\ ${ }^{1}$ Faculty of Electrical Engineering, Universiti Teknologi MARA (UiTM) Shah Alam, Selangor Malaysia \\ ${ }^{2}$ Faculty of Environmental Engineering, National University of Civil Engineering (NUCE) \\ ${ }^{3}$ Universiti Putra Malaysia (UPM) \\ *Corresponding author E-mail: nofri79@yahoo.com
}

\begin{abstract}
Tomato plants are sensitive toward climate changes thus affecting growth development and pollination of the plant. This study was conducted to assess energy performance and environment in greenhouse agriculture to support tomatoes cultivation using Computational Fluid Dynamics (CFD) and OpenStudio EnergyPlus software. To achieve efficient energy performance and to balance it with the environment in tomato greenhouse, architectural and engineering design have been integrated in the study. Analyses on indoor environment and energy consumption of the greenhouse are carried out by installing various electrical equipment such as exhaust fans and humidifier in the greenhouse to meet indoor environment requirement of good tomato cultivation. Three properties of the greenhouse were monitored and these are temperature, relative humidity and energy consumption. Results show that the proposed greenhouse model in this study could meet the required temperature and relative humidity for good tomatoes cultivation.
\end{abstract}

Keywords: Tomatoes cultivation, Greenhouse agriculture, Energy performance,

\section{Introduction}

A new perspective in agricultural sector is to apply protected cultivation such as greenhouse. Greenhouse provides a suitable environment for the intensive production of various crops by carrying out water saving, economical land use, and effective production even in harsh circumstances (Tianyue Wang et al, 2017). To achieve sustainable agriculture with efficient use of energy, both architectural and engineering design needs to be integrated and interacted.

Typically, high tower has been usually used to shield crops from harsh environment such as excessive rainfall, destructive disease and others while depending on natural ventilation. A greenhouse however, is designed to control solar radiation, temperature, and humidity to optimize the crop annual growth and yield. Often, for cooling, heating, and air quality, greenhouse relies on electricity as critical input for effective operation (Barbara.B 2003).

Various crops can be cultivated in the greenhouse and one of them is tomatoes. Tomatoes are sensitive towards climate changes thus affecting growth development and pollination. Tomatoes are categorized under a fruit group which come in many varieties, shapes, sizes, flavours, and colours. Some tomatoes are super-sweet, while others are bright and tangy. For these reasons, energy and climate of tomato greenhouse is chosen in this study.

In constructing a greenhouse, various materials can be used such as polyethylene plastic sheets, polycarbonate sheets, glass, iron steel, PVC and others. Often the material of choice influence indoor environment in the greenhouse, thus affecting the crops. To assess the indoor environment, designers often use various simulation software. Most of the simulation software are capable to do complex calculation, 3d modelling, solar and heat distribution, daylight, four seasons environment, radiance and other factors for complete assessment.

This study intends to model a greenhouse system that meets the indoor environment requirement for good tomatoes cultivation. Electrical equipment such as exhaust fans and humidifier are used for controlling the indoor environment. Energy consumption of the proposed greenhouse is then studied. OpenStudio EnergyPlus (Ahmed,Y, 2013) software is used to assess the indoor environment and energy use, while CFD software is utilized to assess air flow inside the greenhouse. Three properties of the greenhouse are monitored i.e. indoor temperature, relative humidity and energy consumption. The greenhouse is assumed to operate 24 hours, and the simulation was run for an entire year. Kuala Lumpur weather data profile was used to simulate the energy and indoor environment of the greenhouse.

\section{Method}

Prior to the simulation, data collection phase was setup to collect all necessary data required in this study that includes tomatoes cultivation and requirement. Indoor environment requirements for cultivating quality and good tomatoes are very crucial. These informations provide a better understanding on factors that may affect the growth development and pollination of the plants (J.Bentones, 2008; Jabatan Pertanian, 1997). Table 1 shows a summary of the requirement needed for good tomatoes cultivation. This data is used as a benchmark in modelling a suitable greenhouse for tomatoes cultivation in this study. 
Table 1: Tomatoes cultivation requirement

\begin{tabular}{|l|l|}
\hline \multicolumn{1}{|c|}{ Characteristics } & \multicolumn{1}{c|}{ Value } \\
\hline Daily sun exposure & $>6$ hours daily \\
\hline Soil PH level & 6.2 to 6.8 \\
\hline Temperature range & $21 \mathrm{C} \sim 35 \mathrm{C}$ \\
\hline Humidity range & $60 \% \sim 85 \%$ \\
\hline $\begin{array}{l}\text { Irrigation type } \\
\text { intervals }\end{array}$ & Drip irrigation / 2 times/day \\
\hline Plant growth & $\begin{array}{l}\text { Day to bloom - average 50 days } \\
\text { Day to mature - average 100 days }\end{array}$ \\
\hline Light & $\begin{array}{l}\text { Intensity and spectral characteristics, and day length } \\
\text { (Optimum: 1400 lumens, photoperiod 14 hrs). }\end{array}$ \\
\hline
\end{tabular}

In the simulation phase, OpenStudio EnergyPlus software was employed to simulate the greenhouse indoor environment and energy consumption. OpenStudio EnergyPlus is a graphical interface software developed by NREL U.S Departments of Energy for building energy modelling. On the other hand, Autodesk CFD was utilized to study the air flow in the greenhouse. To begin with the simulation, the greenhouse was modelled in $3 \mathrm{~d}$ modelling software using Google Sketchup and AutoCAD. The right architecture and geometry was applied in the modelling to ensure the simulations were as close as the real greenhouse.

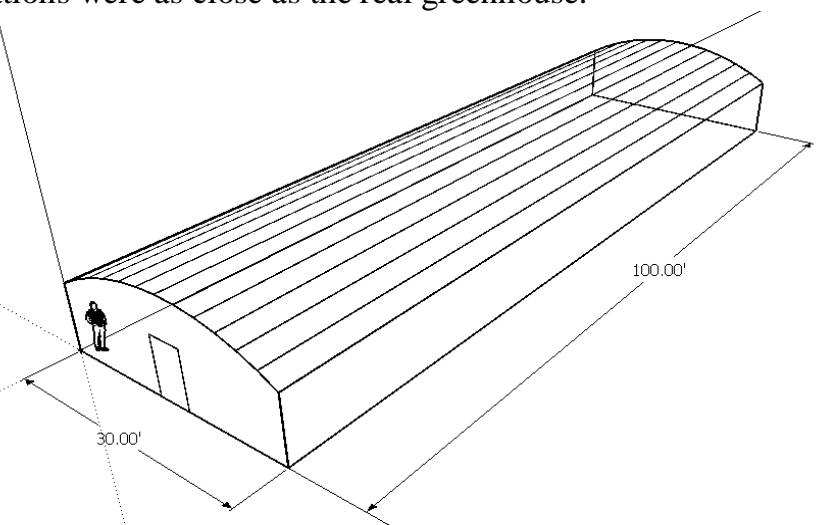

Fig. 1: Greenhouse 3D Modelling using Google Sketcup.

Fig. 1 shows the model of the greenhouse using Google SketchUp The model was drawn using $30 \times 100$-foot measurement with transparent enclosure representing plastic sheets. The model was then imported into OpenStudio EnergyPlus to define the materials used in the construction. Table 2 shows the properties of the materials used in the greenhouse.

Table 2: the properties use in the greenhouse

\begin{tabular}{|l|l|}
\hline Weather Data file & MYS_Kuala.Lumpur.486470_IWEC \\
\hline Site location & Longitude $: 3.12^{\circ}$ \\
& Latitude $: 101.55^{\circ}$ \\
& Elivation $: 22$ \\
& Time Zone $: 8$ \\
\hline Plastic sheet & Materials : Polyethylene (LDPE) \\
& No. of Layer : single layer \\
& Thickness : $0.15 \mathrm{~mm}$ \\
& Visible Transmission $: 90 \%$ \\
& Conductivity : $0.33 \mathrm{~W} / \mathrm{m} . \mathrm{K}$ \\
\hline Iron Steel & Materials : Iron \\
& Roughness: Smooth \\
& Thickness : $25 \mathrm{~mm} / 12 \mathrm{~mm}$ \\
& Conductivity : $45.28 \mathrm{~W} / \mathrm{m} . \mathrm{K}$ \\
& Sspecific Heat $: 500 \mathrm{~J} / \mathrm{kg} . \mathrm{K}$ \\
& Density : $7824.0 \mathrm{~kg} / \mathrm{m}^{3}$ \\
\hline
\end{tabular}

Analyses were performed in this study by installing different electrical appliances in the greenhouse to meet the indoor environment required for good tomatoes cultivation. Three properties of the greenhouse were monitored during simulation i.e. 1) inside temperature, 2) relative humidity, 3) energy consumption. The analyses were performed after the modelling phase was completed using the same OpenStudio EnergyPlus software to run the simulation.
A closed greenhouse can collect and retain heat for a long time thus affecting the crops' growth and pollination. Without proper ventilation, based on Kuala Lumpur weather data file, inside temperature in the greenhouse may vary between $35^{\circ} \mathrm{C}$ to $42^{\circ} \mathrm{C}$ for a period of 7 hours per day. Proper ventilation must be designed to reduce the inside temperature. One of the solution is to use an exhaust fan with enough power to circulate the air and remove the heat. Table 3 shows the properties of the exhaust fan that is integrated in the greenhouse with its operation schedule. Four units of the exhaust fan was installed to reduce the temperature in the greenhouse.

Table 3: Exhaust fan properties

\begin{tabular}{|l|l|}
\hline Specifications & Properties \\
\hline Voltage & $220 \mathrm{~V} \sim 240 \mathrm{~V}(50 / 60 \mathrm{~Hz})$ \\
\hline Power & $36 \mathrm{~W}$ \\
\hline RPM High & 1200 \\
\hline Air Flow (CFM) & 578 \\
\hline Frame Inner Dimension & 350 x 350 mm \\
\hline Run schedule & From 9:00 a.m to 5:00 p.m \\
\hline
\end{tabular}

To study the air flow inside the greenhouse, a CFD software was employed at this stage. The CFD software is capable to simulate the movement of air from one area to another. The CFD software can determine the best airflow that can move the air inside by placing the exhaust fan in the greenhouse, and indirectly reduce the inside temperature.

Other than that, a humidifier was also installed in the greenhouse to improve the relative humidity. Relative humidity is a measure of the amount of water in the air and is usually measured on a relative scale percentage $(\%)$. Although water is used in photosynthesis, most of the water comes from the root and is used in transpiration process that eventually cools down the plant. Relative humidity on the other hand, can affect the plant by slowing down the transpiration process that is if it drops rapidly enough ( $\mathrm{RH}$ drop / increase $20 \%$ in minutes), it will result in tissue damage to the crops. The tomatoes crops are said to be at optimum when the indoor RH is at $50 \%$ and can withstand RH up to $100 \%$. Table 4 shows the humidifier properties that was integrated in the simulation.

Table 4: Humidifier properties

\begin{tabular}{|l|l|}
\hline Model & F748 \\
\hline Voltage & $220 \mathrm{~V}(50 \mathrm{~Hz})$ \\
\hline Humidification & $300 \mathrm{~mL} / \mathrm{h}$ \\
\hline Power & $23 \mathrm{~W}$ \\
\hline Tank Capacity & $4.9 \mathrm{~L}$ \\
\hline Protection & $\begin{array}{l}\text { Auto Power Off } \\
\text { (Running out of water) }\end{array}$ \\
\hline Product weight & $2.75 \mathrm{~kg}$ \\
\hline
\end{tabular}

Other additional loads in the greenhouse included in the simulation are 5 units of LED lighting and single phase 2HP water pump. Both appliances were designed to operate based on timer schedule. The lighting operates for 12 hours from $7 \mathrm{pm}$ to $7 \mathrm{am}$ in the morning, while the pump operates twice daily at maximum of 25 minutes delivering 1 liter of water to the plant. Table 5 shows the properties of the water pump that was integrated in the simulation.

Table 5: Water pump properties

\begin{tabular}{|c|c|}
\hline Model & Okazawa XHM/5A \\
\hline Power & 2 H.P \\
\hline Flow Rate & $600 \mathrm{~L} / \mathrm{M}$ \\
\hline Working Temperature & $0 \sim 40 \mathrm{C}$ \\
\hline Pressure & $224 \mathrm{kPa}$ \\
\hline Weight & $560 \mathrm{~g}$ \\
\hline
\end{tabular}

\section{Results and Discussion}

A closed greenhouse may contribute to higher temperature, higher humidity and lack of aeration thus affecting crop growth. In this study, three properties were monitored to develop a suitable greenhouse indoor environment for tomatoes cultivation. 


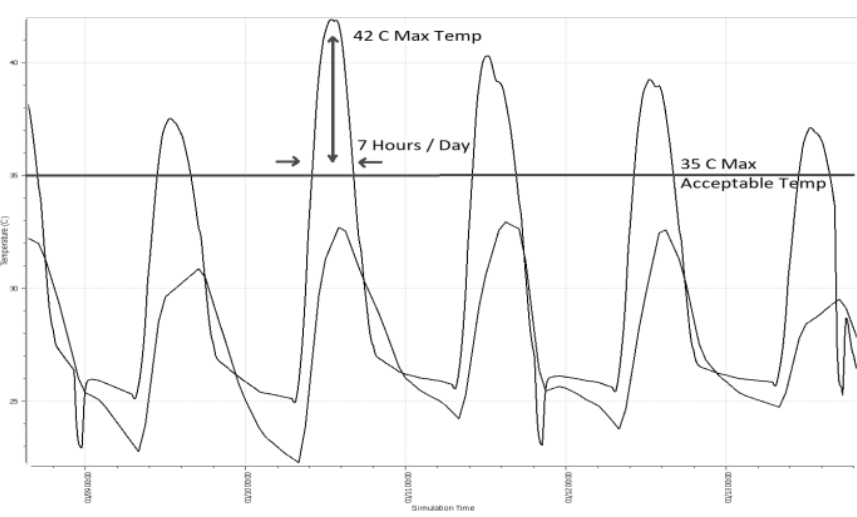

Fig 2 (a) Greenhouse inside temperature prior to exhaust fan installation,

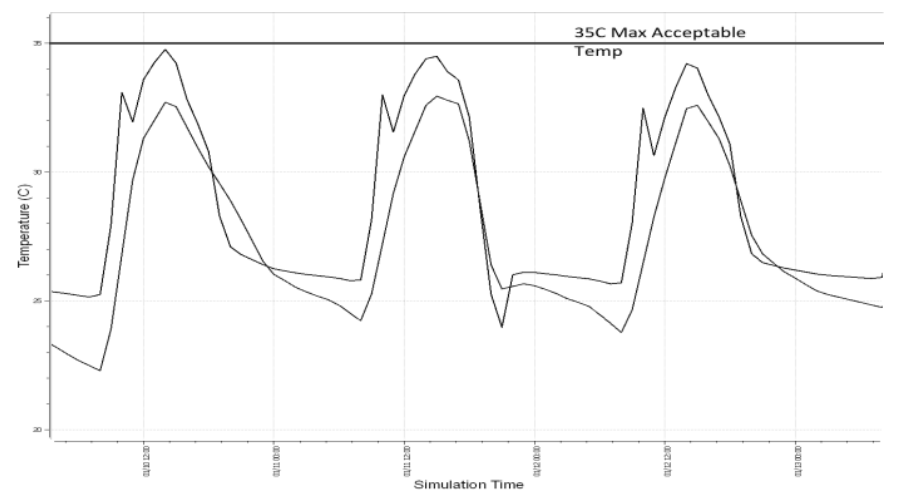

Fig 2(b) Acceptable greenhouse inside temperature after exhaust fan placement.

Fig. 2 shows a comparison of the greenhouse inside temperature before and after exhausts fans placement. In Fig. 2(a), the temperature can rise up to maximum of $40^{\circ} \mathrm{C}$ for up to 7 hours per day. This can kill the tomatoes crop due to dehydration. To control the temperature, four 12' exhaust fans were placed in the greenhouse. The effects can be seen in Fig. 2(b) where the greenhouse inside temperature dropped below $35^{\circ} \mathrm{C}$ of the required temperature.

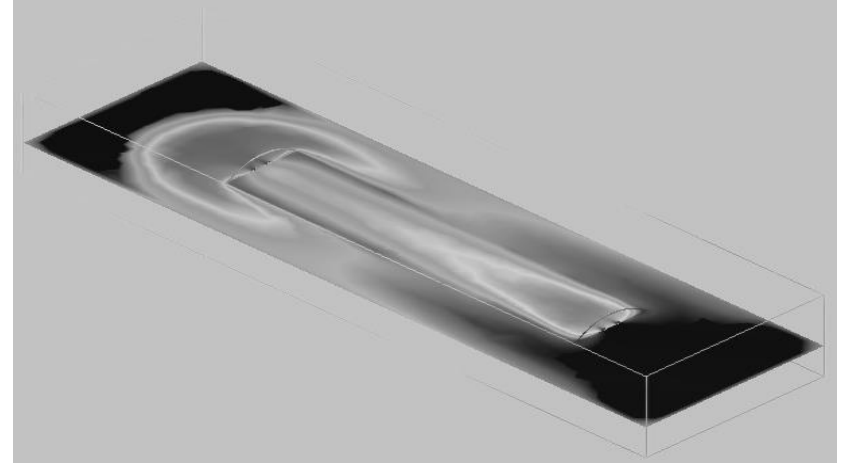

Fig. 3: Air flow analysis using CFD software

To further study the impact of the exhaust fan on the greenhouse, CFD software was employed. Three configurations which were inwards, outwards and balance position were analysed. Fig 3 shows an acceptable configuration of the exhaust fans with balance configuration where one side face inwards and the other side outwards.

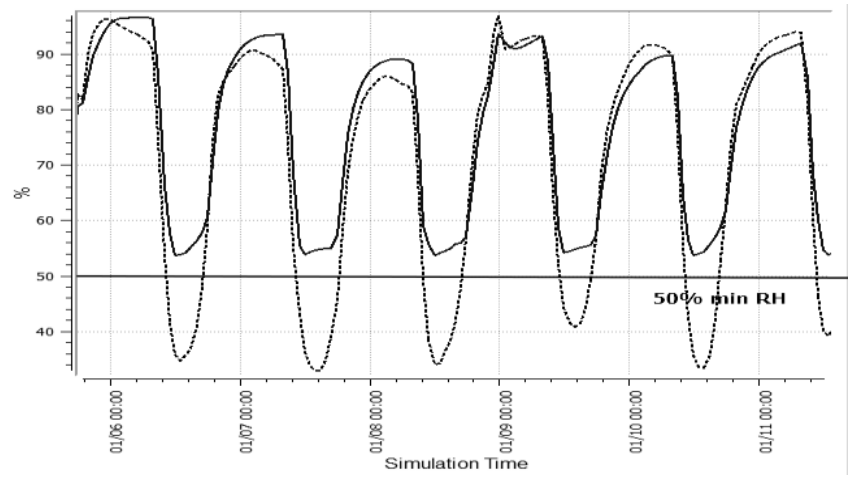

Fig. 4: Comparison of Relative humidity before and after humidifier placements. Solid line - After humidifier placement and dotted line before placement

Fig. 4 shows a graph comparing the relative humidity before and after humidifier is placed inside the greenhouse. The solid line represents the graph after humidifier placement while the dotted line is before the humidifier placement. It can be concluded that the humidifier helps to humidify the condition in the greenhouse above $50 \%$ minimum requirement.

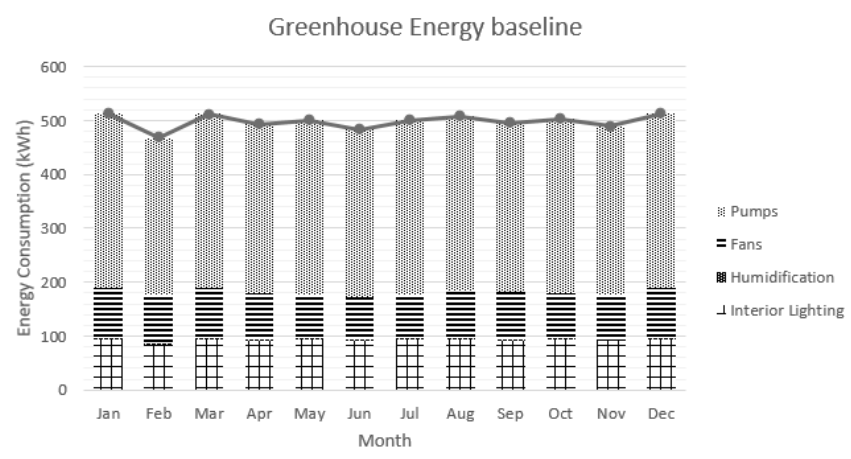

Fig. 5: Energy projection for each month

Table 6: Energy Projection data

\begin{tabular}{|c|c|c|c|c|c|c|c|}
\hline & Jan & Feb & Mar & Apr & May & Jun & Jul \\
\hline Interior & 93.7 & 84.6 & 93.7 & 90.7 & 93.7 & 90.72 & 93.7 \\
\hline Lighting & 4 & 7 & 4 & 2 & 4 & & 4 \\
\hline $\begin{array}{l}\text { Humidifi- } \\
\text { cation }\end{array}$ & 3.19 & 2.83 & 2.29 & 2.8 & 2.11 & 2.65 & 1.88 \\
\hline Fans & $\begin{array}{r}93.4 \\
8\end{array}$ & $\begin{array}{r}88.5 \\
5\end{array}$ & $\begin{array}{r}93.4 \\
2\end{array}$ & $\begin{array}{r}86.8 \\
2\end{array}$ & 81.3 & 77.85 & $\begin{array}{r}81.5 \\
5\end{array}$ \\
\hline Pumps & $\begin{array}{r}322 . \\
68\end{array}$ & $\begin{array}{r}291 . \\
45\end{array}$ & $\begin{array}{r}322 . \\
68\end{array}$ & $\begin{array}{r}312 . \\
27\end{array}$ & $\begin{array}{r}322 . \\
68\end{array}$ & $\begin{array}{r}312.2 \\
7\end{array}$ & $\begin{array}{r}322 . \\
68\end{array}$ \\
\hline Total & $\begin{array}{r}513 . \\
09\end{array}$ & $\begin{array}{r}467 . \\
5\end{array}$ & $\begin{array}{r}512 . \\
13\end{array}$ & $\begin{array}{r}492 . \\
61\end{array}$ & $\begin{array}{r}499 . \\
83\end{array}$ & $\begin{array}{r}483.4 \\
9\end{array}$ & $\begin{array}{r}499 . \\
85\end{array}$ \\
\hline & Aug & Sep & Oct & Nov & Dec & Total & \\
\hline Interior & 93.7 & 90.7 & 93.7 & 90.7 & 93.7 & 1103. & \\
\hline Lighting & 4 & 2 & 4 & 2 & 4 & 76 & \\
\hline $\begin{array}{l}\text { Humidifi- } \\
\text { cation }\end{array}$ & 1.93 & 2.58 & 1.92 & 1.77 & 1.67 & 27.62 & \\
\hline Fans & $\begin{array}{r}89.3 \\
7\end{array}$ & $\begin{array}{r}89.4 \\
8\end{array}$ & $\begin{array}{r}83.8 \\
9\end{array}$ & $\begin{array}{r}84.9 \\
5\end{array}$ & $\begin{array}{r}95.0 \\
7\end{array}$ & $\begin{array}{r}1045 . \\
73\end{array}$ & \\
\hline Pumps & $\begin{array}{r}322 . \\
68 \\
\end{array}$ & $\begin{array}{r}312 . \\
27 \\
\end{array}$ & $\begin{array}{r}322 . \\
68 \\
\end{array}$ & $\begin{array}{r}312 . \\
27\end{array}$ & $\begin{array}{r}322 . \\
68 \\
\end{array}$ & $\begin{array}{r}3799 . \\
26 \\
\end{array}$ & \\
\hline Total & $\begin{array}{r}507 . \\
72\end{array}$ & $\begin{array}{r}495 . \\
05\end{array}$ & $\begin{array}{r}502 . \\
23\end{array}$ & $\begin{array}{r}489 . \\
71\end{array}$ & $\begin{array}{r}513 . \\
16\end{array}$ & $\begin{array}{r}5976 . \\
37\end{array}$ & \\
\hline
\end{tabular}

Fig. 5 shows the energy projection for the greenhouse in one year while table 6 shows the data for energy projection. The energy simulation was carried out based on Kuala Lumpur weather data file as the closest location available. Based on the graph the largest energy user of all the appliances is water pump. On the other hand, the lowest energy consumption is from the humidifier due to its small rating and low usage. 


\section{Conclusion}

This study was performed to model an optimum greenhouse suitable for tomatoes cultivation. In this paper, OpenStudio EnergyPlus and CFD simulation software was employed to study a tomato greenhouse indoor environment, air flow and energy consumption with various electrical equipment installed such as exhaust fan and humidifier. A greenhouse model that meets the indoor environment requirement i.e. inside temperature and humidity for good tomatoes cultivation were developed. The proposed greenhouse model in this study fulfilled the maximum $35^{\circ} \mathrm{C}$ required temperature and minimum $50 \%$ required relative humidity for tomatoes cultivation.

\section{Acknowledgements}

The authors gratefully acknowledge the help of Universiti Teknologi MARA (UiTM) in providing the Lestari Grant (Grant Number: 600-IRMI/DANA 5/3/LESTARI (0167/2016)) for this project.

\section{References}

[1] Tianyue Wanga, Gaoxiang Wua, Jiewei Chena, Peng Cui, Zexi Chena, Yangyang Yana, Yan Zhangc, Meicheng Li, Dongxiao Niuc, Baoguo Li, Hongyi Chene (2017). Integration of solar technology to modern greenhouse in China: Current status, challenges and prospect. Renewable and Sustainable Energy Reviews, 70(2017) 11781188 .

[2] Barbara Bellows,(2003). Solar Green House : Horticulture Resource List. ATTRA Publication, \#IP142.

[3] Ahmed. Y Taha Al-Zubaydi, (2013). Building Models Design And Energy Simulation With Google Sketchup And Openstudio. Journal of Advanced Science and Engineering Research Vol 3, No 4 December (2013) 318-333

[4] J. Bentones Jones Jr. (2008). Tomato Plant Culture: In The Field, Greenhouse and Home Garden. Florida, U.S.A. Taylor \& Francis Group, LLC.

[5] Jabatan Pertanian Semenanjung Malaysia (1997). Pakej Teknologi Tanaman Tomato. Malaysia. Mutucetak Sdn. Bhd. 